\title{
INTERNAL SENSES IN NICHOLAS OF CUSA'S PSYCHOLOGY
}

\author{
Andrea Fiamma \\ Università degli studi ‘G. d'Annunzio’ di Chieti e Pescara
}

\section{Resumen}

En este trabajo se aborda la interpretación de Nicolás de Cusa sobre De anima de Aristóteles, en relación con el funcionamiento de los sentidos internos en el proceso gnoseológico: sensus communis, vis memorialis, vis aestimativa, phantasia y vis imaginativa. Por primera vez en la reciente historiografía sobre la teoría del conocimiento en la Edad Media, las referencias a la doctrina aristotélica de los sentidos internos en la obra de Nicolás de Cusa se organizan dentro de una reconstrucción filosófica sistemática y ordenada; como fuente principal de la doctrina cusana de los sentidos internos, se identifica el Liber de anima de Alberto Magno.

\section{Palabras clave}

Nicolás de Cusa; Aristóteles; Aristotelismo; Historia de la Filosofía medieval; Historia de la Psicología; teoría del conocimiento; percepción

\begin{abstract}
This paper considers Nicholas of Cusa's interpretation of Aristotle's De anima with regard to the functioning of the internal senses in the gnoseological process: sensus communis, vis memorialis, vis aestimativa, phantasia and vis imaginativa. For the first time in the recent historiography on medieval theory of knowledge, the references to the Aristotelian doctrine of the internal senses in Nicholas of Cusa's work are organized in a systematic and ordered philosophical reconstruction; as main source of the Cusanian doctrine of internal senses, Albert the Great's Liber de anima is identified.
\end{abstract}

\section{Keywords}

Nicholas of Cusa; Aristotle; Aristotelianism; History of Medieval Philosophy; History of Psychology; Theory of Knowledge; Perception 


\section{Introduction}

The doctrine of internal senses developed by Aristotle in the second book of De anima has been subject to university debates and commentaries since the XIIIth century, such as those composed by Albertus Magnus, Thomas Aquinas and John of Jandun. This resulted in a corpus of texts as well as the emergence of technical vocabulary in this field. ${ }^{1}$ Curiously, when the later philosopher and connoisseur of Aristotelianism, Nicolaus Cusanus (1401-†1464), addressed this topic, he did not employ the technical language of psychology taught in universities, and explicit references to the aforementioned debates and commentaries are almost entirely absent in his works.

Nicholas of Cusa never deals with the interpretation of the Aristotelian books such as De anima directly, and his texts contain only a few disordered and often inaccurate

\footnotetext{
${ }^{1}$ For a definition of internal senses see reference by Kärkkäinen, P., «Internal senses», in H. Lagerlund (ed.), Encyclopedia of Medieval Philosophy. Philosophy between 500 and 1500, Dordrecht, Springer Netherlands, 2011, pp. 564-567. Concerning the main medieval theories of internal senses, Knuuttila S. and Kärkkäinen P., «Medieval Theories of Internal Senses», in S. Knuuttila and J. Sihvola (eds.), Sourcebook for the History of the Philosophy of Mind. Philosophical Psychology from Plato to Kant, Dordrecht, Springer, 2014, pp. 131-145. Black, D., «Imagination and estimation. Arabic paradigms and Western transformations», Topoi, 11/1 (2000), pp. 59-75, 68, explains that it is not possible to identify a single and unique theory of the internal senses shared by all the medieval commentators of Aristotle; instead, we must speak of a plurality of theories that served as models, not always consistent with each other, and which shared a common approach and a number of details. For example, according to Albertus Magnus, the internal senses are the following: common sense, fantasy, memory, cogitation and instinct (or vis aestimativa); while according to Averroes there are four internal senses and the cogitation has a pre-rational status. Cf. Taylor, R., «Cogitatio, Cogitativus, and Cogitare: Remarks on the Cogitative Power in Averroes», in J. Hamesse and C. Steel (eds.), L'élaboration du vocabulaire philosophique au Moyen âge, Brepols, Turnhout 2000, pp. 111-145. Concerning Avicenna, Averroes and Albert the Great on the Inner Senses, see Tellkamp, J.A., «Vis aestimativa and vis cogitativa in Thomas Aquinas's Commentary on the Sentences», Thomists, 76/4 (2012), pp. 611-640, at pp. 614-621. John of Jandun points out that Averroes connected Aristotelian technical terms such as phantasia and cogitatio; in particular, the cogitatio indicates, for John of Jandun, the totality of logic abilities. Similarly, Nicholas of Cusa, in Sermo CCLXXXV, eds. S. Donati and H.D. Riemann, Nicolai de Cusa Opera omnia, vol. XIX/7, Sermones IV, Fasciculus 7, Hamburg, Meiner, 2005 mentions the faculties of the soul as well as the internal senses (cogitativa, rememorativa, ratiocinativa and electiva), declaring that it is possible to identify "alias tales forma intellectiva formatas» - however he does not express what these are or their specificities. Cf. Albertus Magnus, Summa theologiae, ed. A. Borgnet, Opera omnia, vol. 33, Paris, 1895, vol. II, tr. 8, q. 30, m. 2, p. 327a: «aut est in organis sensuum exteriorum, qui quinque sunt et noti, scilicet visus, auditus, olfactus, gustus, et tactus. Aut est in organis sensuum interiorum, qui etiam quinque sunt, ut dicit Avicenna, scilicet sensus communis, imaginatio sive formalis, phantasia, aestimativa, et memorativa sive memoria». Cf. Park, K., «Albert's Influence on Late Medieval Psychology», in J.A. Weisheipl (ed.), Albertus Magnus and the Sciences: Commemorative Essays 1980, Studies and texts 49, Toronto, Brepols, 1980, pp. 501-535; Steneck, N.H., «Albert the Great on the classification and localization of the internal senses», ISIS, 65/2 (1974), pp. 193-211; Di Martino, C., «Alle radici della percezione. Senso comune e sensazione comune in Aristotele, De anima, III. 1-2», Archives d'Histoire Doctrinale et Littéraire du Moyen Âge, 68/1 (2001), pp. 7-26.
} 
references to the Aristotelian psychology: for example, when he mentions the term sensus in his Compendium, he seems to be referencing only the five external senses, ${ }^{2}$ and he often does not distinguish phantasia from imagination, nor sensitive memory from intellectual memory. Despite this, Nicholas of Cusa dedicates his most important works to the reform of the Aristotelian theory of knowledge, and his library contains copies of Aristotle' De anima and its medieval commentaries, such as Albert the Great.

Research hypothesis: This paper addresses Nicholas of Cusa's interpretation of the doctrines propounded by Aristotle in the second book of De anima, with particular reference to the role of the internal senses in the cognitive process; the sources of the Cusanian doctrine of the internal senses are also discussed, above all the Albert the Great's Liber de anima.

Historiographical context: This article presents, for the first time in the recent historiography, Nicholas of Cusa's sparse suggestions on the Aristotelian doctrine of the internal senses in a systematic and ordered philosophical reconstruction.

What's new for the Cusanus research: This article thus contributes to a more general research on the connection between Aristotelianism and Nicholas of Cusa's philosophy and on the Aristotelian sources of Cusanian works - as Albert the Great -, a focus of international research in recent years. ${ }^{3}$

\section{Internal senses}

Nicholas of Cusa provides a brief list of the internal senses in De querendo Deum, in which he recalls the forms of human knowledge and, for each of these, indicates its designated physiological structures. ${ }^{4} \mathrm{He}$ explains that the first door which must be opened

\footnotetext{
${ }^{2}$ Nicolaus Cusanus, Compendium, ed. K. Bormann, Nicolai de Cusa Opera omnia, vol. XI/3, Hamburg, Meiner, 1964, c. 2, no. 3, 7; Ibid., c. 8, no. 22, 4.

${ }^{3}$ Vimercati, E. and Zaffino, V. (eds.), Nicholas of Cusa and the Aristotelian Tradition. A Philosophical and Theological Survey, Veröffentlichungen des Grabmann-Institutes zur Erforschung der mittelalterlichen Theologie und Philosophie 64, Berlin, De Gruyter, 2020; Maaßen, J., Metaphysik und Möglichkeitsbegriff bei Aristoteles und Nikolaus von Kues, Quellen und Studien zur Philosophie 126, Berlin, De Gruyter, 2015; Fiamma, A., «Nicola Cusano ed Eimerico da Campo: gli anni coloniensi», Medioevo. Rivista di storia della filosofia medievale, 41 (2016), pp. 217-257.

${ }^{4}$ Tellkamp, J.A., «Albert the Great on Structure and Function of the Inner Senses», in R.C. Taylor and I.A. Omar (eds.), The Judeo-Christian-Islamic Heritage. Philosophical and Theological Perspectives, Milwaukee, Marquette University Press, 2012, pp. 305-324, at p. 306: «when it comes to Albert's doctrine of perception and to the role and nature of the sensory faculties of the material mind, he seems to suppose that every process of sensation is necessitated by the fact that animals possess certain organs». On the correspondence between organs and intellectual functions, cf. Stratton, G.M., «Brain localization by Albertus Magnus and some earlier writers», The American journal of Psychology, 43 (1931), pp. 128-131.
} 
in order for the soul to communicate with the external world is the sensus. ${ }^{5}$ Afterwards, the soul elaborates on what the senses perceive through «sensum communem, phantasiam et imaginationem», ${ }^{6}$ which «non excedunt naturam corporalem» ${ }^{7}$ after which the part of the soul which "attingit non corporeum» ${ }^{8}$ is activated. The path of the sensitive species through the virtutes present in the internal senses is as follows: Sensus communis (2), vis memorialis (3), vis aestimativa (4), phantasia (5), vis imaginativa (6).

\section{Sensus communis}

By common sense, Aristotle refers to the sense located in the frontal part of the brain. ${ }^{9}$ When someone perceives an object, it can be simultaneously seen, heard, smelled, tasted or touched. The external senses provide the common sense with five different ways of perceiving a particular object, according to its various qualities: visual, aural, olfactory, gustative and tactile. According to Aristotle, the common sense coordinates the aforementioned perceptions and extracts the communia from them; that is, categories of sensitivity which are common to all of them: motion, rest, form, number and magnitude.

Nicolaus of Cusa rarely mentions these functions of the soul. For example, in Sermo CCIX he states that «omnes sensus quasi rivuli procedunt a sensu communi, qui residet in prima parte cerebri», ${ }^{10}$ that is, the frontal part of the head - as traditionally believed starting from Galen. ${ }^{11}$ When spirits, which are within the external senses, move upward,

${ }^{5}$ Nicolaus Cusanus, De quaerendo Deum, ed. P. Wilpert, Nicolai de Cusa Opera omnia, vol. IV/1, Hamburg, Meiner, 1959, c. 5, no. 49, 10.

${ }^{6}$ Ibid., no. 49, 14.

${ }^{7}$ Ibid., no. 49, 14-15.

${ }^{8}$ Ibid., no. 49, 15-16. Cf. Thomas de Aquino, Summa theologiae, ed. Fratrum Praedicatorum, Sancti Thomae de Aquino Opera omnia iussu Leonis XIII P. M., t. V, Summa theologiae, I⿳a q. 50-119 edita., Roma, 1889 , at q. 84 , a. 7: «incorporalium non sunt aliqua phantasmata; quia imaginatio tempus et continuum non transcendit».

${ }^{9}$ Aristoteles, De anima III, 1 425a27. Cf. Albertus Magnus, Liber de anima, ed. C. Stroick, Alberti Magni Opera omnia, vol. VII, 1, Münster, Aschendorff 1968, vol. II, t. 4, c. 7; Augustinus Hipponensis, De libero arbitrio, ed. J. Migne, S. Aurelii Augustinii Opera omnia, PL 32, l. II-III, 8-27 instead refers to the «sixth internal sense».

${ }^{10}$ Nicolaus Cusanus, Sermo CCIX, ed. J. Leicht, Nicolai de Cusa Opera omnia, vol. XIX/0, Sermones IV, Fasciculus 0, Hamburg, Meiner, 2008, no. 5, 19-21.

${ }^{11}$ On common sense in Ancient Philosophy, see Heller-Roazen, D., «Common Sense. Greek, Arabic, Latin», in S. Nichols and G.A. Kablitz and A. Calhoun (eds.), Rethinking the Medieval Senses. Heritage / Fascinations / Frames, Baltimore, The Johns Hopkins University Press, 2008, pp. 30-50. For the medieval theories, see the Witelo, Epistula de primaria causa poenitentiae in hominibus et de substantia et natura daemonum, ed. E. Paschetto, Demoni e prodigi: note su alcuni scritti di Witelo e di Oresme, Torino, Giappichelli, 1978, pp. 89-132, at p. 107: the information acquired through the five external senses merge in the common sense, which is located in the frontal side of the head. Witelo states that epilepsy, known since ancient times, is explained in terms of damage to the common sense: in men affected by the disease, communication between the external senses and imagination is interrupted; imagination, therefore, begins working on its own. Regardless, the images produced 
carrying sensitive impressions with them, gather in the frontal part of the head, then move gradually toward the back of the head. The common sense «est positus super omnem sensum» ${ }^{12}$ from both a physical and epistemological point of view, just as Nicolaus Cusanus explains - the sense of hearing is placed above audible things, ${ }^{13}$ conversely, the particulares ${ }^{14}$ and external senses «sunt in regno sensus communis». ${ }^{15}$

In the common sense, the soul is the first to consider that the different perceptions received by the five senses all belong to a single object in a specific place, which either moves or stays still and which is of a certain size or quantity. Nicolaus Cusanus claims that in the common sense there is a "generalem sentiendi virtutem ${ }^{16}$ that drives perception by understanding the object in a unitary way, but without distinguishing between its attributes and without subjecting it to a categorical analysis. ${ }^{17}$ Lastly, the common sense is the faculty which connects different species originating from the external senses, according to their categories of sensitivity. ${ }^{18}$

are deposited in the memory and, consequently, epileptic sometimes claim to have had extraordinary experiences. Federici Vescovini, G., Medioevo magico: la magia tra religione e scienza nei secoli XIII e XIV, Torino, UTET, 2008, p. 93.

${ }^{12}$ Nicolaus Cusanus, De quaerendo Deum, op. cit., c. 1, no. 24, 2-3. Albertus Magnus, Liber de anima, op. cit., II, tr. 4, c. 7, believes that common sense is exercised by a cellula present in the brain. See Albertus Magnus, Liber de sensu et sensato, ed. S. Donati, Alberti Magni Opera omnia, vol. VII, 2A, Münster, Aschendorff 2017, vol. I, c. 10, 25b.

${ }^{13}$ Nicolaus Cusanus, De quaerendo Deum, op. cit., c. 1, no. 24, 4-5: «sicut auditus super audibilia, gustus gustabilia, olfactus odorabilia, tactus tangibilia».

${ }^{14} \mathrm{Ibid}$, c. 1, no. 30, 4-5.

${ }^{15}$ Ibid., c. 1, no. 30, 7-9.

${ }^{16}$ Nicolaus Cusanus, De beryllo, ed. K. Bormann and H.G. Senger, Nicolai de Cusa Opera omnia, vol. XI/1, Hamburg, Meiner, 1988, c. 38, no. 71, 3. See Nicolaus Cusanus, De ludo globi, ed. H.G. Senger, Nicolai de Cusa Opera omnia, vol. IX, Meiner, Hamburg 1998, I, no. 26, 10-11: «anima est substantia incorporea et virtus diversarum virtutum»; concerning this definition of soul, see Albertus Magnus, Liber de anima, op. cit., vol. III, tr. 2, c. 12 (p. 193, 1-8), of whose work Cusanus had a copy: Fiamma, A., «Nicholas of Cusa and the so-called Cologne School of the 13th and 14th Centuries», Archives d'Histoire Doctrinale et Littéraire du Moyen Âge, 84 (2017), pp. 91-128, at p. 100.

${ }^{17}$ Nicolaus Cusanus, De coniecturis, ed. J. Koch and C. Bormann, Nicolai de Cusa Opera omnia, vol. III, Hamburg, Meiner, 1972, I, c. 8, no. 32: «sensus animae sentit sensibile, et non est sensibile unitate sensus non exsistente; sed haec sensatio est confusa atque grossa, ab omni semota discretione. Sensus enim sentit et non discernit. Omnis enim discretio a ratione est; nam ratio est unitas numeri sensibilis. Si igitur per sensum discernitur album a nigro, calidum a frigido, acutum ab obtuso, hoc sensibile ab illo, ex rationali hoc proprietate descendit. Quapropter sensus ut sic non negat, negare enim discretionis est; tantum enim affirmat sensibile esse, sed non hoc aut illud. Ratio ergo sensu ut instrumento ad discernendum sensibilia utitur; sed ipsa est, quae in sensu sensibile discernit».

${ }^{18}$ In the critical edition of Nicolaus Cusanus, De aequalitate, ed. H.G. Senger, Nicolai de Cusa Opera omnia, vol. X/1, Opuscula II/1: De aequalitate - Vita erat lux hominum, Hamburg, Meiner, 2001, no. 6, 56 , p. 9, the curator Senger points out that «hic loquitur de sensu communi nec sec. doctrinam aristotelico-scholasticam (cf. e. g. Aristotelem De an. III $1425 \mathrm{a} 27$ et saepius) nec de illo, quem Augustinus nominavit interiorem (cf. e. g. De lib. arbit. II III. 8. 27; p. 241, 74s); sed respicit ad sensum 


\section{Vis memorialis}

In the second book of De anima, Aristotle mentions the memorative sense as the second internal sense. ${ }^{19}$ The memorative sense is the place where the product of the common sense and, as shall be seen, of phantasia, ${ }^{20}$ come together. However, the passages where Nicolaus Cusanus touches upon the existence of the memorative sense in humans are few and far between, nor of great significance within the text. For example, in Sermo CLXXIV, he explains that "post sensationem ${ }^{21}$ there is a certain force or faculty of the soul which elaborates on the image of objects. These images are carried by a «vapore purgato ${ }^{22}$ to the back of the head, where «thesauros memoriae» ${ }^{23}$ are found.

In the same Sermo, several references to Albertus Magnus's commentary on Aristotle's De anima are found. However, unlike Albertus Magnus, Cusanus only mentions the function of the memory to preserve, but - surprisingly - grants it little importance within the entire cognitive process. ${ }^{24}$ For instance, Nicholas of Cusa, in De docta ignorantia, ${ }^{25}$ apparently refers to memory, in the Aristotelian sense, as the place where some products of phantasiis ${ }^{26}$ are found. He writes that these are the phantasmata: «coloris

unum communemque omnium (de quo v. Ciceronem Tim. (ad 42a) c. 1244 [181b]) et absolutum, modo dicto de materia communi (no. $5,4 \mathrm{~s}) »$.

${ }^{19}$ Concerning the role of memory in the Aristotelian knowledge's process, cf. Sorabji, R., Aristotle on Memory, London, Duckworth, 1972, repr. Chicago, Chicago Univ. Press, 2006; Annas, J., «Aristotle on Memory and the Self», in M.C. Nussbaum and A.O. Rorty (eds.), Essays on Aristotle's De Anima, Oxford, Clarendon Press, 1992, pp. 297-311.

${ }^{20}$ Cusanus uses the term memory but without specifying whether it should be understood as the internal sense where the species of things have their place, or whether it refers to a second kind of memory which is seen, according to the Augustinian tradition, as the place of exemplaria. This section aims to trace those passages where Cusanus mentions memory exclusively in the former sense. On the function of memory in Aristotelian tradition, cf. Bloch, D., «Averroes Latinus on Memory. An Aristotelian Approach», Cahiers de l'Institut du Moyen-Âge grec et latin, 77 (2006), pp. 128-131.

${ }^{21}$ Nicolaus Cusanus, Sermo CLXXIV, ed. J. Leicht, Nicolai de Cusa Opera omnia, vol. XVIII/0, Sermones III, Fasciculus 0, Hamburg, Meiner, 2007, no. 12, 17.

${ }^{22}$ Ibid., no. 12, 19-20.

${ }^{23}$ Ibid., no. 12, 20-21.

${ }^{24}$ Albertus Magnus, Liber de anima, op. cit., II, t. 3, c. 6. See Cod. Cus. 96, f. 251vb in Nicholas of Cusa's library, corresponding with Albertus Magnus's commentary on Dionysius, Letter IX; Cusanus writes on that folio: «memoria est pars sensitive non intellective». On Albertus Magnus's conception of memory see Anzulewicz, H., «Memoria und reminiscentia bei Albertus Magnus», in A. Parravicini Bagliani (ed.), La mémoire du temps au Moyen Âge, Micrologus' Library 12, Firenze, SISMEL Edizioni del Galluzzo, 2005, pp. 163-200, concerning Albert's commentary on De anima at p. 176-178 and the introduction to the translation of Albert's book on memory in german language edited by Müller, J., Albertus Magnus über Gedächtnis, Erinnern und Wiedererinnerung. Eine philosophische Lektüre von De memoria et reminiscentia mit Übersetzung, Lectio albertina 17, Münster, Aschendorff, 2017.

${ }^{25}$ Nicolaus Cusanus, De docta ignorantia, ed. E. Hoffmann and R. Klibansky, Nicolai de Cusa Opera omnia, vol. I, Lipsia, Meiner, 1932., II, c. 2, no. 103, 9-14.

${ }^{26}$ Ibid., no. 103, 9. 
aut soni aut alterius», ${ }^{27}$ yet «informis». ${ }^{28}$ Indeed, they wait to be processed through reason. In De coniecturis, Cusanus refers to memory as the place where images from the phantasia are preserved. ${ }^{29}$

In the fourth chapter of the Compendium, Cusanus states that the activity of phantasia is imprinted in the memory and stored for a while «uti vocabula manent in charta scripta prolatione cessante». ${ }^{30}$ The analogy of the written paper, inspired by the Aristotelian wax tablet, confirms that for Cusanus, the function of the memorative sense is limited to the remanentia of sensitive species. Even in this instance, it is not possible to establish the source used by Cusanus, as there are not sufficient features to identify either an Aristotelian or Augustinian doctrine.

\section{Vis aestimativa}

Albertus Magnus, following Avicenna, defines the vis aestimativa as the internal sense which allows one to perceive the intention of an external object. ${ }^{31}$ This internal sense, located in the frontal part of the head of humans, also belongs to animals devoid of reason and it manifests itself in their everyday life in the form of instinct: for example, when the birds flee from an imminent danger and move themselves towards what they judge to be a more advantageous position. Albertus Magnus adds that there is an aestimatio present in humans as well, produced by phantasia and operating in the same way as it does in animals. ${ }^{32}$ Due to its own characteristics, this kind of judgement can cause some passions,

${ }^{27}$ Ibid., no. 103, 10.

${ }^{28}$ Ibid., no. 103, 10.

${ }^{29}$ Nicolaus Cusanus, De coniecturis, op. cit., II, c. 14, no. 145, 12-16: «in virtute humanitatis homo in superiori parte sensibili, puta phantastica, creat similitudines aut imagines sensibilium, quia unitas, in qua aequalitas et conexio. Ipsas vero creatas imagines ordinat atque locat, quia aequalitas, in qua unitas et conexio. Post haec ipsas conservat in memoria».

${ }^{30}$ Nicolaus Cusanus, Compendium, op. cit., c. 4, no. 9-10: «in istis igitur signorum designationibus in interiori phantastica virtute manent res designatae, uti vocabula manent in charta scripta prolatione cessante; quae remanentia memoria potest appellari».

${ }^{31}$ Albertus Magnus, Liber de anima, op. cit., II, tr. 4, c. 7, 17-20: «in prima autem parte mediae cellae cerebri, quae calida est ex motu multi spiritus ad ipsam, posuerunt aestimativam, quae elicitiva et activa est intentionum»; Ibid., III, tr. 1, c. 2, p. 167, 35s.; Albertus Magnus, Summa de creaturis - de homine, ed. H. Anzulewicz and J.R. Soder, Alberti Magni Opera omnia, vol. XXVII, Münster, Aschendorff, 2008, 1. II, tr. 1, no. 37.

${ }^{32}$ Albertus Magnus, Liber de anima, op. cit., III, tr. 1, c. 3, p. 168, 25: «de phantasia [...] dicimus ipsam esse potentiam componentem imagines cum intentionibus et intentiones cum imaginibus et imagines cum imaginibus et intentiones cum intentionibus». However, this must not lead to phantasia being identified with instinct; indeed, - Albertus Magnus clarifies - «oportet igitur phantasiam secundum aliquid esse differentem ab imaginatione et aestimativa. Licet enim omnes istae potentiae passivae animae sint et patiantur a formis individuis, quae sunt principia cognitionis sensibilis, quae formae eaedem esse videntur, tamen modus passionis non est idem, sed est secundum differentem gradum abstractionis». For a definition of that faculty, see below. 
such as fear or anger, both in humans and in animals ${ }^{33}$. In fact, in our experience, it happens sometimes that a force of instinct reveals itself in us, activates our fears or our desires and induces us to react instantly without having to undergo rational elaboration.

The Aristotelianism had already observed the manifestation of instinct as a vis aestimativa. Albertus Magnus mentions the example, first elaborated by Avicenna, ${ }^{34}$ of the wolf and the sheep: due to the vis aestimativa, the sheep instinctively runs away at the sight of the wolf, while at the sight of the sheep, the wolf instinctively tries to capture it. Avicenna highlights that both the sheep and the wolf's reactions would not have been possible through the external senses, which only perceive the form and shape of the wolf..$^{35}$ Rather, under these circumstances, each animal understands the instinctive will of the other: the sheep recognises the harmful intentions of the wolf, not, as Thomas Aquinas also explains, because it receives sensitive species in the wolf's colour or form which prompts it to escape, but rather because it perceives, by means of such internal sense called vis aestimativa, that the wolf is its «inimicum naturae». ${ }^{36}$

Similarly, Nicholas of Cusa, in the Compendium, explains that each animal «facit imaginationem quam aliud et aliam aestimationem amicitiae aut inimicitiae, convenientis aut disconvenientis quam aliud», ${ }^{37}$ on the basis of the species which reaches their senses. It should be noted that the vis aestimativa produces a weakened sort of judgement, located at the sensible level of phantasia rather than of ratio. ${ }^{38}$ There is no

${ }^{33}$ Albertus Magnus, De animalibus, ed. B. Geyer, Alberti Magni Opera omnia, vol. XII, Münster, Aschendorff, 1955, l. VII, tr. 1, c. 1, no. 2: «passiones autem dico, sicut est timor, audacia, ira, libido luxuriae: et in hiis etiam cetera animalia communicant. In quibusdam autem eorum invenitur etiam quaedam vis, quae est sicut cogitativa et compositiva sive collativa in homine: et haec vocatur a quibusdam cogitativa sensibilis, a quibusdam autem fantasia componens et dividens». On the same topic, see Thomas Aquinas, Summa theologiae, op. cit., I, q. 78, a. 4.

${ }^{34}$ Black, D., «Estimation in Avicenna: The Logical and Psychological Dimensions», Dialogue, 32 (1993), pp. 219-258. Cf. Oelze, A., Animal Rationality: Later Medieval Theories 1250-1350, Investigating Medieval Philosophy 12, Leiden, Brill, 2018, at p. 34 (on Avicenna) and pp. 59-69 (on Thomas Aquinas).

${ }^{35}$ Avicenna, Liber de anima I, c. 5, 85-86. Black, D., «Imagination and Estimation», op. cit., pp. 5975. Bottin, F., Filosofia medievale della mente, Padova, Il Poligrafo, 2005, p. 222: «tra i dati istintivi Avicenna colloca tutte le proprietà non sensibili connesse con il sentire quali l'ostilità, l'amore, l'amicizia, come pure tutti i moti istintivi del vivente nel suo ambiente, ivi comprese le tendenze innate che governano i viventi, quale l'istinto del neonato a succhiare o la protezione della prole da parte della madre».

${ }^{36}$ Thomas Aquinas, Summa theologiae, op. cit., I, q. 78, a. 4. Tellkamp, J.A., «Vis aestimativa and vis cogitativa», op. cit., p. 621. Cf. Piro, F., " Animalité et connaissance animale. Notes sur la doctrine de l'estimative et sur ses interprétations en Occident », in T. Gontier (ed.), Animal et animalité dans la philosophie de la Renaissance et de l'Âge Classique, Leuven, Peeters, 2005, pp. 131-151.

${ }^{37}$ Nicolaus Cusanus, Compendium, op. cit., c. 6, no. 16, 12-14.

${ }^{38} \mathrm{Ibid}$., no. 16, 11-13: «vis phantastica unius animalis ex speciebus per sensus receptis aliam facit imaginationem quam aliud et aliam aestimationem amicitiae aut inimicitiae». Cf. Albertus Magnus, De animalibus, op. cit., XXI, tr. 1, c. 2, 1329: «aestimativa brutorum iudicet de intentionibus quae cum sensibilibus accipiuntur». Cf. Pluta, O., «Mental representation in animals and humans. Some late 
doubt for Cusanus that this force of instinct is pre-rational. Is it also irrational? What is the relationship between instinct and reason in men?

When Cusanus speaks of vis aestimativa, he refers to animals devoid of reason («mente enim carentes») $)^{39}$ and free will («carent libera virtute, quae in nobis est»); ${ }^{40}$ nonetheless, observing their instinctive actions, Cusanus recognizes a cunning of the species that almost suggests the presence of reasonableness. This becomes evident when we observe how birds and spiders, driven by instinct, build their nests and how they act when hunting. ${ }^{41}$ Cusanus believes that even in these activities «non sine ratione haec fiunt». ${ }^{42}$ He also notes that animals of the same species behave the same way and for all it is effective and functional to their purposes. The instinct, as a result, reflects reason and it is precisely under the basis of this reflexion that it is possible to establish an affinity between humans and animals. ${ }^{43}$

These instinctive actions of animals show a similarity with human smart activities driven by reason. ${ }^{44}$ Although the animal «movetur imperio naturae necessitante ipsum, non inductione rationis, quam ignorat», ${ }^{45}$ a certain intelligence, cunning and pragmatism which drives its nature is manifested. ${ }^{46}$. Therefore, «in uno motu specifico videmus omnia eiusdem speciei tamquam ex indita lege naturae compelli et moveri». ${ }^{47}$ On the other hand, not all animals reflect this intelligence in the same way: some of them, such as spiders, which weave webs, have a greater capacity than others. ${ }^{48}$ Nevertheless, this

medieval discussions», in K. Gyula (ed.), Intentionality, Cognition, and Mental Representation in Medieval Philosophy, New York, Fordham University Press, 2015, pp. 273-286.

${ }^{39}$ Nicolaus Cusanus, De coniecturis, op. cit., I, c. , no. 7, 3-5: «rationalis fabricae naturale quoddam pullulans principium numerus est; mente enim carentes, uti bruta, non numerant».

${ }^{40}$ Nicolaus Cusanus, De ludo globi, op. cit., I, no. 34, 6 .

${ }^{41}$ Ibid., no. 34, 10-14: «bestiae vero non sic. Ideo impelluntur ad ea quae agunt per naturam et eiusdem speciei similes faciunt venationes et nidos».

${ }^{42}$ Ibid., no. 34, 15.

${ }^{43}$ Albertus Magnus, De animalibus, op. cit., VII, tr. 1, c. 1, no. 2: «aestimatio autem talis maxime inest apibus propter opera artificiosa, quae faciunt, et propter yconomicam et regnum, quod custodiunt domestice et civiliter collaborantes»; Thomas Aquinas, Summa theologiae, op. cit., I, q. 78, a. 4: «avis colliget paleam [...] quia est utilis ad nidificandum».

${ }^{44}$ Toivanen, J., « Entre la raison et la perception. La psychologie animale médiévale et la relation entre les humains et les animaux », in M. Cutino, I. Iribarren and F. Vinel, La restauration de la création, Vigiliae Christianae 145, Leiden, Brill, 2017, pp. 275-297 distinguishes between a metaphysical and a psychological-functional difference between man and animal in most of the philosophical theories of the XI-XV centuries; however, he underlines the feeling of common similarity between man and animal generally widespread in the centuries of the so-called late Middle Ages. On that topic, cf. Steel, C.G., Guldentops, G. and Beullens, P. (eds.), Aristotle's animals in the Middle Ages and Renaissance, Leuven, Leuven University Press, 1999.

${ }^{45}$ Nicolaus Cusanus, De ludo globi, op. cit., I, no. 35, 4-5.

${ }^{46}$ Ibid., no. 35, 1: «natura movetur intelligentia».

${ }^{47}$ Ibid., no. 35, 5-7.

${ }^{48}$ Nicolaus Cusanus, De coniecturis, op. cit., II, c. 10, no. 121, 1-7: «motus etiam animalium progressivus, secundum quem animalia a vegetabilibus differunt, non tantum ad corporis, sed ad 
reasonableness, which is intrinsic to all natures of animals (and humans), can be found in their vis aestimativa. ${ }^{49}$

\section{Phantasia}

In De anima, Aristotle defined phantasia as the internal sense designed to produce the phantasmata - namely, the formal representations of perceived things which are developed from the elements of the common sense and memory. ${ }^{50}$ It is also responsible for formulating sensitive images, which stimulates the instinct. These products of phantasia pertain strictly to the will, rather than to the epistemological system, and they are linked with the vis aestimativa.

Due to its ability to combine and connect the species stored in the memory, phantasia can occasionally assume the function of memory itself, as we will see later on. For example, when an animal is encountered for the first time, the senses perceive its sensitive qualities and phantasia can elaborate a unitary image by connecting it with similar animals encountered previously. Consequently, the soul can recognize the similarity between this animal and others by means of its physical or behavioural features, even without any memory of something connected to it. ${ }^{1}$

animae etiam debet necessitatem referri. Nam non tantum animal locum mutat, ut necessarium nutrimentum colligat, sed et ideo etiam, ut animae operationes perficiat. Nec animal unum aliud vincit volatu, cursu industriaque eo tantum, quia his eget conservanda eius complexio, sed et quia haec et spiritus exquirit».

${ }^{49}$ Nicolaus Cusanus, Compendium, op. cit., c. 6, no. 18.

${ }^{50}$ Aristoteles, De anima, III, 3, 428b11-429a, 1-4. Aristotle's idea about the role of phantasia has been subject of debate in recent studies. For an overview of the state of progress of research cf. Nussbaum, M.C. and Rorty, A.O. (eds.), Essays on Aristotle's De anima, Oxford, Clarendon Press, 1992. Concerning the medieval definition of phantasia, see for exemple: Albertus Magnus, Liber de anima, op. cit., III, tr. 1, c. 3, p. 168, 25: «de phantasia [...] dicimus ipsam esse potentiam componentem imagines cum intentionibus et intentiones cum imaginibus et imagines cum imaginibus et intentiones cum intentionibus». For a clarification of the medieval definitions of the term, cf. Köhler, T.W., «Imaginatio / phantasia bei Mensch und Tier. Aspekte philosophischer Urteilsbildung nach veröffentlichten und unveröffentlichten Quellen des 13. Jahrhunderts», in M.C. Pacheco and J.F. Meirinhos (eds.), Intellect et imagination dans la Philosophie Médiévale, vol. II, Turnhout, Brepols, 2006, pp. 1085-1098.

${ }^{51}$ Albertus Magnus, Summa de creaturis - De homine, op. cit., II, q. 38, a. 3. However, the function of recognition is not the same between animals and men: despite the fact that animals process prerational images in the same way as humans, they cannot compare these images with each other; this happens instead in men, in which cogitation is present. Cf. Toivanen, J., Perception and the Internal Senses. Peter of John Olivi on the Cognitive Functions of the Sensitive Soul, Leiden, Brill, 2013, p. 239: "Aquinas thinks that the estimative power is more sophisticated in humans than in other animals. Animals apprehend the intentions only instinctively, whereas humans do this by means of a certain comparison (per collationem quandam). The estimative power even has a different name in the case of human beings: Aquinas calls it the cogitative power (cogitatio)». De Haan, D.D., «Perception and 
Nicholas of Cusa affirms that phantasia is located at the top of the head and that its task is to produce phantasms, that is, the sensitive images of things. ${ }^{52}$ In De mente, phantasia takes its place among the spirits flowing in the blood, of which the sense of touch is the heaviest and largest, while the sense of sight is the lightest and finest. Phantasia is a "spiritus quidam multo tenuior et agilior spiritui per arterias diffuso»; ${ }^{53}$ unlike the other five spirits, it is too light to reach the organs of the external senses and to participate in perceptive activity. Because of its features, it remains bound to the highest part of the head, in the cellula phantastica. ${ }^{54}$ The sensitive soul can use the spirit as an instrument, in the same way as it uses the spirits of the arteries ${ }^{55}$.

Nicolaus Cusanus, argued that the perceiving soul employs the spirits of the arteries, directed toward the senses, in order to fulfil its desire for knowledge ${ }^{56}$ The spirit of the arteries is given the role of transmission, leading the sensitive soul to the sense organs. Without this spirit, the sensitive soul could not perceive species which reach the sense organs: the species of sight are collected in the eye, those of the hearing in the ear and, similarly, phantasms are gathered in the cellula phantastica.

The sensitive soul gathers information provided by the external senses through the blood, where the spirits of the arteries flow, leading to an understanding of the perceived object. The spirits which flow in the blood are instruments for the soul to understand species, while the organ of senses «quasi fenestrae sunt et viae, per quas spiritus ille ad sentiendum exitum habet».57

When the soul makes use of the spirit of phantasia, it does not require any sense organs: its proper place is in the highest part of the head. Therefore, the physiological disposition of the cellula phantastica manifests the kind of knowledge which comes from the sensitive soul using it: the phantasms, produced internally in the head, are more formal and precise than the sensitive species which originate from the re-elaboration of the materials interacting with the external senses..$^{58}$

the Vis Cogitativa. A Thomistic Analysis of Aspectual, Actional, and Affectional Percepts», American Catholic Philosophical Quarterly, 88/3 (2014), pp. 397-437.

${ }^{52}$ Nicolaus Cusanus, De coniecturis, op. cit., II, c. 14, no. 145, 12-14: «in virtute humanitatis homo in superiori parte sensibili, puta phantastica, creat similitudines aut imagines sensibilium».

${ }^{53}$ Nicolaus Cusanus, De mente, ed. L. Baur and R. Steiger, Nicolai de Cusa Opera omnia, vol. V, Hamburg, Meiner, 1983, c. 8, no. 114, 9-10.

${ }^{54}$ Ibid., no. 114, 9: «in prima parte capitis».

${ }^{55}$ Ibid., no. 114, 10: «pro instrumento».

${ }^{56}$ Ibid., no. 114, 1: «cum ergo spiritus ille instrumentum sit sensuum».

${ }^{57}$ Ibid., no. 114, 1-3. The sensory perception occurs by means of the soul (forma formans) and the species, which reach the sensory organ (forma informans), and through the spirit of the arteries, which connects the soul with the organs of external senses. Likewise, the production of the phantasmata happens by means of the sensitive soul (forma formans), the product of the common sense (forma informans), and the spirit of phantasia, which links the soul to the cellula phantastica.

${ }^{58}$ Nicolaus Cusanus, Compendium, op. cit., c. 4, no. 9, 10-12: «quare signa rerum in imaginatione seu phantastica remotiora sunt a materia et magis formalia, hinc quoad sensibilia minus perfecta et 
Consequently, Nicholas of Cusa affirms that if the soul uses the instrument of phantasia, it gains all that is needed for understanding and does not need to receive any additional information by means of the external senses: in this way the cosmographer described by Cusanus in Compendium, after learning that «omnem sensibilis mundi [...] designationes $»^{59}$, then «nuntios [...] licentiat, clauditque portas» ${ }^{60}$. It is important now to consider the circumstances in which the sensitive soul relies on phantasia. This connection is intended by Cusanus - as will be shown below - in a similar way to the psychological interpretation in Albert the Great's commentary on Aristotle's De anima.

In De mente, Cusanus explains that the sensitive soul employs the spirits of the external senses in order to perceive an external object. The sensitive soul receives the species of the object from these spirits. One of the limits of sensitive perception is that it fundamentally depends on the reception of the external senses: this kind of knowledge is only possible if the external object is physically present in front of the subject perceiving it. Knowledge of the outside world through perception is exclusively achieved when the object is present and when the external senses can collect the species of the object into the quantity and the quality necessary to allow this perception.

However, it is a regular occurrence that some species are missed in perception; for instance, it may be the case that the visual species are not present while the auditory ones are, such as when the voice of a known person is heard but this person is not seen. In this case, the soul recurs to the spirit of phantasia by recalling information stored in the memory and linking up this information, so the soul is still able to recognise the person's face from whom the voice is heard, despite the absence of visual species.

Phantasia intervenes where perceptible content is lacking, and offers the sense of reason a phantasm drawn from memory. ${ }^{61}$ By connecting the information, phantasia is

quoad intelligibilia perfectiora». Thomas de Aquino, De veritate, ed. Fratrum Praedicatorum, Sancti Thomae de Aquino Opera omnia iussu Leonis XIII P. M, t. 22, vol. II/1, Quaestiones disputatae de veritate, q. 8-12, Roma, 1970, q. 8, a. 12 affirms that angels do not have phantasms available to them because, being devoid of body, they do not possess internal senses but only intelligible species which derives from the intellect, cf. Summa theologiae, op. cit., q. 89, a. 1 e a. 2. Cf. Pasnau, R., Theories of Cognition in the Later Middle Ages, Cambridge, Cambridge University Press, 1997, p. 194; Cohen, S.M., «St. Thomas Aquinas on the Immaterial Reception of Sensible Forms», Philosophical Review, 91/2 (1982), pp. 193209, at pp. 201-205.

${ }^{59}$ Nicolaus Cusanus, Compendium, op. cit., c. 8, no. 23, 1-2.

${ }^{60}$ Ibid., no. 23, 4.

${ }^{61}$ Augustinus Hipponensis, De trinitate, ed. J. Migne, S. Aurelii Augustinii Opera omnia, PL 42, 1. VIII, 9, where the relation between memory and phantasia is discussed: Augustine of Hippo explains that when he pronounces the name of a city either he knows it, such as Carthage, or he does not, such as Alexandria; the faculty of representation, using memory, furnish the mind with the phantasmata of these cities. In the first case the imagination draws Carthage's species directly from the memory, where they have been stored since he saw this city; in the second case, phantasia creates Alexandria's species by gleaning discourses and stories heard about the city from memory. In this latter case, therefore, phantasia submits some sensitive species to reason, even though they have never been perceived with the senses. 
therefore able to form phantasmata of the object even though it is not available to one or more external senses. The action of phantasia, however, is not always successful, and very often it provides wrong or misleading phantasms. ${ }^{62}$ Nicholas of Cusa frequently presents the case of a man born blind who cannot perceive colours. ${ }^{63}$ Indeed, «si porta aliqua civitatis suae semper clausa remansit, puta visus, tunc quia nuntii visibilium non habuerunt introitum, defectus erit in descriptione mundi». ${ }^{64}$

It is impossible for the blind man to have an adequate understanding of the world because he lacks the visual species, and he cannot compensate for sight with either phantasia or memory, since nothing can reach the memory without first having been

${ }^{62}$ Albertus Magnus, De somno et vigilia, ed. A. Borgnet, Alberti Magni Opera omnia, vol. IX, Paris, 1890, p. 121-212, at l. II, tr. 1, c. 4, no. 162b: «quoniam vero de phantasia diximus in libro de Anima, secundum quod sub se comprehendit et imaginativam et aestimativam, patet quod phantasticum subjecto idem est sensibili, sed esse suum formale et diffinitivum non est idem cum esse sensibilis. Est autem phantasia motus ille qui fit a sensu secundum actum facto, sicut diximus in libro de Anima. Dico autem phantasiam formaliter cum suis formis accipiendo: motum autem voco formam ad ipsam in spiritu animali devectam: somnium autem quoddam phantasma videtur esse per experta. Diximus enim quod hoc phantasma quod est in somno, est aut simpliciter factum, aut quodammodo: non simpliciter factum dicimus esse somnium: manifestum est igitur, quoniam partis sensibilis animae est somniare, non quidem sensibilis, secundum quod simpliciter est sensibile, quia sic fit in actu ab exterioribus, sed sensibilis est secundum quod sensibile efficitur».

${ }^{63}$ Nicolaus Cusanus, Apologia doctae ignorantiae, op. cit., no. 3, 3s.; Nicolaus Cusanus, Cribratio Alchorani, ed. L. Hagemann, Nicolai de Cusa Opera omnia, vol. VIII, Hamburg, Meiner, 1986, 1. I, no. 6, 59: «et quoniam nihil experimur in nostro intellectu comprehendi, quod per sensum in ipsum non intrat - caecus enim a nativitate scientiam coloris non habet -, scimus bonum illud non esse de regione huius sensibilis mundi quodque spiritus noster in hoc mundo ad quietem non perveniet»; Nicolaus Cusanus, De coniecturis, op. cit. II, c. 6, no. 100, 6-7: «caeco enim praecisio coloris per visum percepta nullo sermone communicari potest»; Ibid., no. 157, 19-20: «nec nos attingimus sensibile ut tale absque sensu, caecus enim sensibilem colorem non attingit»; Nicolaus Cusanus, De deo abscondito, ed. P. Wilpert, Nicolai de Cusa Opera omnia, vol. IV/1, Hamburg, Meiner, 1959, no. 5, 14-16: «nonne amens iudicaretur ille caecus, qui se putaret scire differentias colorum, quando colorem ignoraret».

${ }^{64}$ Nicolaus Cusanus, Compendium, op. cit., c. 8, no. 22, 11-13. 
perceived by the senses. ${ }^{65}$ For this reason - as Cusanus writes in Compendium - «caecus a nativitate non habet phantasma coloris et imaginari nequit colorem». ${ }^{66}$

Similarly, in the Apology, Nicholas of Cusa mentions the example of a blind man who is convinced that he has a knowledge of the sun; ${ }^{67}$ this is due to the fallacy of phantasia, which is sometimes deceptive: «potest enim caecus aliquis multa audisse de solis claritate atque quod tanta sit, quod comprehendi nequeat, credens se per ea, quae sic audivit, scire aliqua de solis claritate, cuius tamen habet ignorantiam». ${ }^{6}$

${ }^{65}$ Ibid., c. 4, no. 9, 5: «nihil enim est in phantastica, quod prius non fuit in sensu». Cusanus adheres to the traditional Thomist doctrine of knowledge per phantasmata, derivated from Aristotle's De anima. Concerning Aristotelian theory, cf. Cohoe, C., «When and Why Understanding Needs phantasmata: a Moderate Interpretation of Aristotle's De memoria and De anima on the Role of Images in Intellectual Activities», Phronesis, 61/3 (2016), 337-372. Regarding the Thomist's interpretation of Aristotle, cf. Thomas Aquinas, De veritate, op. cit., q. 2 a. 3 arg. 19: «praeterea, nihil est in intellectu quod non sit prius in sensu. Sed in Deo non est ponere sensitivam cognitionem, quia materialis est. Ergo ipse non intelligit res creatas, cum non sint prius in sensu». Cf. Stump, E., «Aquinas on the Mechanisms of Cognition: Sense and phantasia», in S. Ebbesen and R.L. Friedman (eds.), Medieval Analyses of Language and Cognition, Copenhagen, C.A. Reitzels, 1999, pp. 377-395. Concerning Cusanus, see also: Sermo CLXXXVII, ed. S. Donati and H. Schwaetzer and F.-B. Stammkötter, Nicolai de Cusa Opera omnia, vol. XVIII, III/4, Hamburg, Meiner, 2004, p. 345B: «ideo ad cognitionem Dei non potest homo pervenire ex omnibus viribus suis, cum nihil sit in humano intellectu, quod medio sensuum ad eum non perveniat»; Nicolaus Cusanus, Sermo LXIV, ed. M.-A. Aris and H. Hein and H. Schnarr, Nicolai de Cusa Opera omnia, vol. XVII, II/5, Hamburg, Meiner, 2006, p. 357A: «quare et obviantia, quae vinci debent, necesse est apparentissima esse et talia, quae sua ostensione maxime impugnent fidem, uti est certitudo, quae est in sensibus, quoniam, cum nihil sit in intellectu, quod prius non fuit in sensu, maximae virtutis fidei est intellectum captivare, ut id credat, cuius oppositum ostendit sensus»; Nicolaus Cusanus, Sermo CXXVII, ed. R. Haubst e H. Pauli, Nicolai de Cusa Opera Omnia, vol. XVIII, III/1, Hamburg, Meiner, 1995, p. 28A: «si igitur nec auris audivit nec oculus vidit nec in cor hominis intravit, tunc homo non potest dicere, quid sit. Et si quis diceret, ille non esset purus homo. Et quando annuntiaret seu evangelizaret regnum, non intellegeretur, quia nihil in intellectu, quod prius non fuit in sensu»; Nicolaus Cusanus, Sermo CLVIII, ed. H. Pauli, Nicolai de Cusa Opera omnia, vol. XVIII, III/2, Hamburg, Meiner, 2001, p. 174A: «nota quod, sicut ille qui rem laudat penitus omni sensu incognitam non potest bene intellegi, quia nihil est in intellectu, quod prius non fuit in sensu, si contingeret, quod ostenderetur res laudata sensibiliter, tunc omnia priora, quae auditu recepit quasi fide, inciperet visu attingere, et quae prius capere non potuit, nunc clare vera esse conspiceret».

${ }^{66}$ Nicolaus Cusanus, Compendium, op. cit., c. 4, no. 9, 6-7.

${ }^{67}$ Nicolaus Cusanus, Apologia doctae ignorantiae, ed. R. Klibansky, Nicolai de Cusa Opera omnia, vol. II, Lipsia, Meiner, 1932, no. 3, 3s. The example is introduced as a literary device to denounce the arrogance of Scholastic theologians; on this theme cf. Fiamma, A., «Nicolaus Cusanus and the University Philosophy: Paris, Cologne and Leuven», in H. Schwaetzer and M.-A. Vannier (eds.), Nikolaus von Kues: Die Großregion als Denk- und Lebensraum, Texte und Studien zur Europäischen Geistesgeschichte - Reihe B 20, Münster, Aschendorff Verlag, 2019, pp. 89-100; Fiamma, A., Nicola Cusano da Colonia a Roma (1425-1450). Università, politica e umanesimo nel giovane Cusano, Texte und Studien zur Europäischen Geistesgeschichte - Reihe B 19, Münster, Aschendorff Verlag, 2019, 281s.

${ }^{68}$ Apologia doctae ignorantiae, op. cit., no. 3, 3-7. 
On the basis of perceptions offered by the other sense organs, the phantasia of the blind man constructs a phantasm of the sun; but this is misleading: there are no phantasms which can represent the brightness of the sun, as it exceeds all perceptions. Conversely, thanks to the visual species, those with sight can experience that the brightness of the sun exceeds every species: therefore they admit to not having an understanding of the sun in itself ${ }^{69}$.

\section{Vis imaginativa}

In De mente, Nicolaus of Cusa affirms that the internal sense of imagination releases a spirit which spreads throughout the body and which is «ad omnes sensibiles species configurabilis». ${ }^{70}$ Cusanus sometimes attributes some functions to the vis imaginativa which Aristotle ascribed to phantasia: in the same text Nicholas of Cusa states that imagination «in absentia sensibilium» $»^{71}$ behaves «ut sensus aliquis absque discretione sensibilium $\rangle^{72}$ : it produces a phantasm of the object. This phantasm lacks the contents of perception, therefore knowledge is realised in a confused way. ${ }^{73}$

Nicholas of Cusa maintains that when the sensitive soul uses the spirit of phantasia "pro instrumento» ${ }^{74}$ in order to understand the shape of something «etiam re absentata», ${ }^{75}$ this "vis [...] imaginatio dicitur, quoniam per eam anima rei absentatae imaginem sibi conformat». ${ }^{76}$ Thus phantasia "a sensu differt qui, solum re praesente, formam comprehendit in materia, imaginatio vero re absentata». ${ }^{77}$ It is important to understand whether phantasia and imagination, for Cusanus, «sunt idem», ${ }^{78}$ as Thomas Aquinas maintained, ${ }^{79}$ or whether he believed that imagination has a specific role in human cognitive faculties as a whole.

In De coniecturis, imagination is qualified as «rationalis ignobilis» ${ }^{80}$ and is identified as the inferior medium of the four-part scheme of the human soul - intellect, reason, imagination, and sense - which Nicolaus of Cusa finds in Albertus Magnus's commentary

\footnotetext{
${ }^{69} \mathrm{Ibid}$., no. 3-7-9: «videns vero de solis claritate, quanta sit, interrogatus respondit se ignorare et huius ignorantiae scientiam habet, quia, cum lux solo visu attingatur, experitur solis claritatem visum excellere».

${ }^{70}$ Nicolaus Cusanus, De mente, op. cit., c. 7, no. 102, 1-2.

${ }^{71}$ Ibid., no. 100, 5.

${ }^{72}$ Ibid., no. 100, 5-6.

${ }^{73}$ Ibid., no. 100, 6 .

${ }^{74}$ Ibid., c. 8, no. $114,11$.

${ }^{75}$ Ibid., no. $114,11$.

${ }^{76}$ Ibid., no. 114, 8-9.

${ }^{77}$ Ibid., no. 114, 11-12.

${ }^{78}$ Thomas Aquinas, Summa theologiae, op. cit., I, q. 78, a. 4.

${ }^{79}$ Nicolaus Cusanus, De coniecturis, op. cit., II, c. 11, no. 130, 11-12.

${ }^{80}$ Ibid., c. 16, no. 157, 10s: «haec sunt quasi animae humanae quattuor elementa».
} 
on De anima. ${ }^{81}$ Each corresponds to a different level of understanding; taking as an example a man who comes across a ball: through the senses, in particular the «sensus autem visus», ${ }^{82}$ this man does not perceive the ball as a perfect «sphaeram, sed partem», ${ }^{83}$ that is, an uneven sphere. However, after perceiving the ball, the rational soul intervenes and discovers, at the level of reason, the roundness of the ball. Indeed, «per rationem, partem cum parte componentem attingitur $\rangle^{84}$ and a ball «rotundam atque corpoream $»^{85}$ is imagined.

Imagination links together the elements of perception and integrates them with the species of the round ball which is stored in the memory; but it is only by means of the highest part of the reason that a man knows the shape of the ball. This level of understanding consists of possessing the notion of a round ball as that object which «habet omnes lineas a centro ad circumferentiam esse aequales». At this point, however, we have already entered the level of reason - therefore we abandon the comment of that text. ${ }^{86}$

The same four-part structure of the human faculties is stated again by Cusanus in De ludo globi: imagination here is considered as a virtue employed by the rational soul, similar to the man who uses a walking stick as an aid to cross a ditch encountered while walking. ${ }^{87}$ Firstly, the man relies on phantasmata ${ }^{88}$ and then, via intellect, leaves these phantasmata so that «ad veritatem, quae imaginationem excedit, quam solum quaerit, perveniat». ${ }^{89}$ Consequently, it is not possible to grasp from these pages the fundamental differences between phantasia and imagination.

However, it must be noted that phantasia is usually connected to instinct, or vis aestimativa, while imagination is followed by the assimilation of intellect to a thing, a

${ }^{81}$ Ibid., no. 168, 5. On Albertus Magnus: Anzulewicz, H., «Vermögenspsychologische Grundlagen kognitiver Leistung des Intellektes nach Albertus Magnus», Acta Mediaevalia, 22 (2009), pp. 95-116, at p. 103.

${ }^{82}$ Nicolaus Cusanus, De coniecturis, op. cit. II, no. $168,6$.

${ }^{83}$ Ibid., no. 168, 6-7

${ }^{84}$ Ibid., no. 168, 4-5: «dum in phantasia ipsum intuetur, ipsam rotundam atque corpoream imaginatur».

${ }^{85}$ Ibid., no. 168, 3-4.

${ }^{86}$ The image of the center and the circumference, as well as the reference to the roundness, are, however, not of Aristotelian origin; rather, it is possible to find a source in the School of Chartres's works, cf. Albertson, D., Mathematical Theologies: Nicholas of Cusa and the Legacy of Thierry of Chartres, Oxford, Oxford University Press, 2014; Rusconi, C., "Cusanus und Thierry von Chartres. Die Einleitung der Spekulativen Wissenschaften und der Begriff forma essendi in De possest und im Kommentar Libum hunc», in H. Schwaetzer and K. Zeyer (eds.), Das europäische Erbe im Denken des Nikolaus von Kues: Geistesgeschichte als Geistesgegenwart, Münster, Aschendorff Verlag, 2008, pp. 285302.

${ }^{87}$ Nicolaus Cusanus, De ludo globi, op. cit., II, no. 88, 9: «imaginatio igitur adiuvat mentem sibi coniunctam»; Ibid., no. 88, 15-16: «quasi saltator fossati baculo».

${ }^{88}$ Ibid., no. 88, 11-12: «sunt autem phantasmata, quae offert imaginatio».

${ }^{89}$ Ibid., no. 88, 14-15. 
process by which man understands the external world. ${ }^{90}$ In this way, in De mente, Nicolaus of Cusa compares the soul to a malleable wax, able to adapt and configure itself to the images of things introduced by the imagination..$^{91}$ As the spirit of the arteries adapts to the sensitive species that come from the senses, the assimilating force conforms to the intelligible species.

In this context, the vis imaginativa is described by Nicholas of Cusa as the faculty of the soul able to take images of external things and make them more abstract and subtle. These external things are also called species, preparing the abstraction realized by the rational soul. ${ }^{92}$ The imagination can combine phantasms and create new images regardless of the contents of the memory: this is the reason why we are able to think of figures which we have never seen, such as the unicorn or the chimera. Cusanus follows also in this case the traditional topics of the Aristotelian theory of the internal senses, describing imagination on the boundary between the ability of phantasia to separate and combine images, and that of human reason to abstract and discern concepts.

\section{A special focus on abstraction}

Nicholas of Cusa explained that the vis imaginativa works by abstracting images from the perceived material. It must be specified that the process of abstraction, which is realized by this internal sense (i.e. the phantasia), does not correspond to the same process of abstraction that is found at the level of reason: the sensitive images that it derives in this phase of the cognition are not yet suitable for being received by reason. It is necessary to wait for the intervention of the light of the intellect which, illuminating the sensitive

${ }^{90}$ Nicolaus Cusanus, De mente, op. cit., c. 7, no. 99, 10. Nicolaus Cusanus, Compendium, op. cit. c. 10, no. 32, 5-6: "cognitio vero fit per similitudinem»; knowledge consists of the "assimilatio intellectus ad rem», cf. Thomas Aquinas, De veritate, op. cit., q. 1, a. 1: the rational soul of men, indeed, through its assimilating force, conforms to the species of the object. Nicolaus Cusanus, Compendium, op. cit., c. 10, no. 32, 3-4: «obiectum sensitivae cognitionis non est nisi aequalitas, sic et imaginativae atque etiam intellectivae»; in fact, the soul «naturaliter potentia suum cognoscit obiectum». Nicolaus Cusanus, De aequalitate, op. cit., no. 27,13-15 explains that «sine aequalitate non intelligitur veritas, quae est adaequatio rei et intellectus, non est nec vita nec esse nec tempus nec motus nec continuum».

${ }^{91}$ Nicolaus Cusanus, De mente, op. cit., c. 7, no. 100, 11-15: «unde spiritus ille subtilis arteriarum, qui est mente animatus, per mentem ad similitudinem speciei, quae obstaculum praestitit motui, spiritui sic conformatur sicut cera flexibilis per hominem mentis usum ac artem habentem configuratur rei praesentialiter artifici praesentatae».

${ }_{92}$ Nicolaus Cusanus, De docta ignorantia, op. cit. II, c. 6, no.125; c. 9, no. 142 e 150; Nicolaus Cusanus, De mente, op. cit., c. 7, no.104, 1; Nicolaus Cusanus, De venatione Sapientiae, ed. R. Klibansky and H.G. Senger, Nicolai de Cusa Opera omnia, vol. XII, Hamburg, Meiner, 1982, c. 6, no.15, 5; c. 36, no. 107, 2-8. Cf. Fiamma, A., «Der menschliche Geist und die Universalienbegriffe bei Nikolaus von Kues. Eine einführende Themenskizze», in C. Stroebele (ed.), Singularität und Universalität im Denken des Cusanus, Regensburg, Roederer Verlag, 2015, pp. 53-71. 
images, operates an abstraction under the aspect of pure form. However, this further analysis falls outside the circumscribed perimeter of the present study.

Nicholas of Cusa in his works dedicates numerous passages to the description of rational abstraction and only a few references to the sensitive abstraction of phantasia. For exemple in Sermo CLXXIV, Nicolaus of Cusa explains the process of abstraction by comparing it to the process of digestion. ${ }^{93}$ Taking as an example a man who eats some bread: first he breaks down the bread with his teeth, then he digests it in the stomach, «ut separetur subtile a grosso» ${ }^{94}$ Four stages of digestion then follow, which make the bread finer and softer until it is "convertatur in naturam aliti». ${ }^{95}$ These stages of digestion are compared with the four levels of knowledge: namely, perception, imagination, rational knowledge, and intellectual knowledge.

of particular interest is the method of digestion: the raw material at the first level is gradually made finer and softer so as to be useful for the higher levels. This thinning's process (subtiliatio) ${ }^{96}$ takes place through a process of separation and distinction, which concerns both the bread and the species of things, resulting in «digestiones abstractivas». ${ }^{97}$ Consequently, each item of knowledge is produced by a process of assimilation which consists of discernment and abstraction. Nicholas of Cusa has probably read the metaphor of digestion in Albertus Magnus's commentary on Aristotle's De anima, ${ }^{98}$ where digestion is mentioned as a bodily process in which the stomach extracts nourishment from ingested food. Describing a similar process, Nicholas of Cusa in a sermon states that «separationes rerum quae pascere debent intellectum». ${ }^{99}$ Furthermore, in the Nota which closes the sermon, he points out that «Albertus Magnus in libro suo De anima dicit quod abstrahere non sit nisi simplificare». ${ }^{100}$ Also in this circumstance it emerges that Nicholas of Cusa uses the fundamental schema of Aristotelian physiology, making explicit the reference to Albert the Great.

\section{Conclusion}

This article has examined Cusanus's position with regard to the establishment and functioning of the internal senses. Some passages from his main epistemological texts,

\footnotetext{
${ }^{93}$ Nicolaus Cusanus, De docta ignorantia, op. cit. III, c. 9, no. 236, 4-9: «contrario modo se habent corporalia et spiritualia. Virtus enim vegetativa corporalis est, quae convertit alimentum ab extrinseco receptum in naturam aliti; et non convertitur animal in panem, sed e converso. Spiritus autem intellectualis, cuius operatio est supra tempus quasi in horizonte aeternitatis, quando se ad aeterna convertit, non potest ipsa in se convertere, cum sint aeterna et incorruptibilia».

${ }^{94}$ Nicolaus Cusanus, Sermo CLXXIV, op. cit., no. 2, 5-6.

${ }^{95}$ Ibid., no. 2, 10.

${ }^{96} \mathrm{Ibid}$, no. 2, 12.

${ }^{97}$ Ibid, no. $3,1$.

${ }^{98}$ Albertus Magnus, Liber de anima, op. cit., II, tr. 2, c. 5 (VII, p. 89, 79-80).

${ }^{99}$ Nicolaus Cusanus, Sermo CLXXIV, op. cit., no. 2, 11-12.

${ }^{100}$ Ibid., no. 12, 1-3.
} 
such as De coniecturis, De mente, Compendium and De ludo globi, have been analysed. It has been demonstrated that Cusanus did not develop an original position regarding the theory of internal senses, but that he refers frequently and acritically to the medieval interpretations of Aristotle's De anima, such as the one in Albert the Great's commentary.

In this paper, however, it has also been shown that it is not methodologically possible to think of Cusanus' philosophy without considering the influence of the Aristotelian thought. In fact, too often the recent research on Cusanian thinking is excessively dedicated to finding traces of Renaissance Neo-Platonism in his works. Instead the Aristotelian books such as De anima are the fundamental ground on which Cusanus grafted the seed of his philosophy. ${ }^{101}$

Further research will be required to determine how consistent the influence of Aristotelianism was on Nicolaus Cusanus's psychology.

\author{
Andrea Fiamma \\ andrea.fiamma@hotmail.it
}

Fecha de recepción: 17/09/2020

Fecha de aceptación: 02/11/2020

${ }^{101}$ The XVth century German Neoplatonism must be understood in the light of the Aristotelian tradition and according to the pedagogical requirements of University teaching: see for exemple the works of Heymerich de Campo (1395-†1460), a close friend of Nicholas of Cusa. Cf. Korolec, J.B., «Heymeric de Campo et sa vision néoplatonicienne de Dieu», in A. Zimmermann (ed.), Albert der Grosse. Seine Zeit, Sein Werk, Seine Wirkung, Miscellanea Mediaevalia 14, Berlin-New York, De Gruyter, 1981, pp. 208-216; Hoenen, M.J.F.M., «Heymeric van de Velde (†1460) und die Geschichte des Albertismus: Auf der Suche nach den Quellen der albertistischen Intellektslehre des Tractatus problematicus», in M.F.J.M. Hoenen and A. De Libera (eds.), Albertus Magnus und der Albertismus. Die deutsche philosophische Kultur des Mittelalters, Leiden, Brill, 1995, pp. 303-331; Imbach, R., «Quelques remarques sur le traité De sigillo eternitatis de Heymeric de Campo», Ibid., pp. 297-302; Anzulewicz, H., «Zum Einfluss des Albertus Magnus auf Heymericus de Campo», in K. Reinhardt (ed.), Heymericus de Campo. Philosophie und Theologie im 15. Jahrhundert, Regensburg, Roederer Verlag, 2009, pp. 83-112; Meliadò, M., Sapienza peripatetica. Eimerico di Campo e i percorsi del tardo albertismo, Dokimion 40, Münster, Aschendorff Verlag, 2018. 
